\title{
Angiostrongylus vasorum and Aelurostrongylus abstrusus: Neglected and underestimated parasites in South America
}

\author{
Felipe Penagos-Tabares ${ }^{1,2^{*}}$, Malin K. Lange ${ }^{1}$, Jenny J. Chaparro-Gutiérrez ${ }^{2}$, Anja Taubert ${ }^{1}$ and Carlos Hermosilla ${ }^{1}$
}

\begin{abstract}
The gastropod-borne nematodes Angiostrongylus vasorum and Aelurostrongylus abstrusus are global causes of cardio/ pulmonary diseases in dogs and cats. In the last decade, the number of reports on canine and feline lungworms has increased in several areas of Europe and North America. The unspecific clinical signs and prolonged course of these diseases often renders diagnosis challenging. Both infections are considered as emerging and underestimated causes of disease in domestic pets. In South America, little information is available on these diseases, apart from occasional reports proving the principle presence of $A$. vasorum and $A$. abstrusus. Thus, the purpose of this review is to summarize reports on infections in both domestic and wildlife animals in South America and to increase the awareness on gastropod-borne metastrongyloid parasites, which also include important zoonotic species, such as A. cantonensis and $A$. costaricensis. This review highlights the usefulness of diagnostic tools, such as the Baermann funnel technique, serology and PCR, and proposes to include these routinely on cases with clinical suspicion for lungworm infections. Future national epidemiological surveys are recommended to be conducted to gain a deeper insight into the actual epidemiological situation of gastropod-borne parasitoses in South America.
\end{abstract}

Keywords: Angiostrongylus vasorum, Aelurostrongylus abstrusus, Gastropod-borne diseases, Lungworms, Metastrongyloidea

\section{Background}

The gastropod-borne metastrongyloid parasites Angiostrongylus vasorum and Aelurostrongylus abstrusus are known to affect the cardiopulmonary system of canids and the respiratory tract of felids, respectively [1]. These potentially pathogenic parasites have recently gained attention from the veterinary community due to their spread beyond the borders of known endemic areas, mainly in European countries as well as in North America [1-11]. Although they have been reported in both, domestic and wild canids/felids in different South American countries (see Table 1) [12-16], suggesting an endemic presence of both parasites in these regions, only a few epidemiological surveys haven been conducted on these parasites in the past decades. This indicates a neglected and underestimated status of these parasitoses not only by the Latin

\footnotetext{
* Correspondence: Felipe.penagos@udea.edu.co

${ }^{1}$ Institute of Parasitology, Justus Liebig University Giessen, 35392 Giessen, Germany

${ }^{2}$ CIBAV Research Group, Veterinary Medicine School, University of Antioquia, 050034 Medellin, Colombia
}

American veterinary but also by the parasitology community. Thus, more epidemiological research is required to obtain actual, consistent and detailed data on their epidemiology and actual disease occurrence and on the impact of canine angiostrongylosis and feline aelurostrongylosis on domestic and wild canid/felid populations in South America, as already performed in Europe [2, 3].

It is well known that both canine angiostrongylosis and feline aelurostrongylosis can lead to certain diagnostic challenges due to the intermittent excretion of first-stage larvae (L1), the high variability of clinical signs and the frequently occurring chronic and subtle course of infections $[2,17,18]$. In addition, a reliable definitive diagnosis based on clinical-pathological, serological, molecular or coprological approaches is challenging, since all conventional diagnostic methods may fail due to certain deficiencies and limitations of each diagnostic method [2]. The best diagnostic tool for the detection of $A$. vasorum or $A$. abstrusus first larvae in faeces is still represented by the Baermann funnel migration technique, which is unfortunately rarely utilized in small animal veterinary clinics of 
Table 1 Reports on Angiostrongylus vasorum infections in definitive hosts in South America

\begin{tabular}{llll}
\hline Definitive host species & Geographical location & No. of cases & Reference \\
\hline Cerdocyon thous & Gioás and Angra Dos Reis, Rio de Janeiro, Brazil & 1 & Travassos, 1927 [49] \\
Cerdocyon thous/Canis familiaris & Brazil & na & Dougherty, 1946 [141] \\
Cerdocyon thous/ Canis familiaris & Colombia and Rio Grande do Sul, Brazil & 1 & Gonçalves, 1961 [13] \\
Canis familiaris & Rio de Janeiro, Brazil & na & Langenegger et al., 1962 [54] \\
Canis familiaris & Rio de Janeiro, Brazil & na & Grisi, 1971 [50] \\
Canis familiaris & Paraná, Brazil & na & Giovannoni et al, 1985 [55] \\
Canis familiaris & Minas Gerais, Brazil & na & dos Santos et al., 1985 [56] \\
Canis familiaris & Argentina & na & Venturini \& Borel, 1991 [58] \\
Lycalopex (syn. Dusicyon) vetulus & Minas Gerais, Brazil & $4 / 8$ & Lima et al., 1994 [12] \\
Lycalopex gymnocercus & Bolivian Chaco & $1 / 10$ & Fiorello et al., 2006 [82] \\
Cerdocyon thous & Minas Gerais, Brazil & $3 / 6$ & Duarte et al., 2007. [57] \\
Nasua nasua & Paraná, Brazil & 1 & Vieira et al., 2008 [52] \\
Eira barbara & Mato Grosso do Sul, Brazil & 1 & Vieira et al., 2008 [52] \\
Cerdocyon thous & Pereira, Colombia & 1 & Varela-Arias et al., 2014 [59] \\
Cerdocyon thous & Federal District, Midwestern Brazil & Ferreira-Júnior et al., 2017 [142] \\
Cerdocyon thous & Minas Gerais, Brazil & 1 & Viera et al., 2017 [143] \\
\hline Abbrition:
\end{tabular}

Abbreviation: na, not applicable

South America [19] even though it is a cheap and easy diagnostic method [20]. As a consequence, only fragmentary information on the true geographical distribution and actual prevalence of these nematodes is available in South and Central America [19, 21].

Overall, some cases of both canine angiostrongylosis and feline aelurostrongylosis were described in several regions of South America (Fig. 1). Furthermore, some reports exist on a specific intermediate host species, the highly invasive terrestrial African giant snail Achatina fulica [22-24]. Between 1988 and 1989 this invasive neozoan snail species, originating from East Africa, was introduced to South America (especially to Brazil) for the commercial heliculture industry (snail farming) for human consumption [25]. Since then, this species rapidly spread throughout several South American countries, including Argentina, Colombia, Ecuador, Paraguay, Peru and Venezuela [26]. More importantly, A. fulica is considered as the most harmful invading terrestrial snail species on Earth $[27,28]$ and therefore might contribute to the spread of the here reviewed lungworms and other closely related anthropozoonotic metastrongyloid parasites, such as Angiostrongylus costaricensis and A. cantonensis as already reported for the Americas [24, 25].

The geographical expansion of lungworm infections, which was reported for several countries $[4,10,29,30]$ throughout the last decades, may rely on climate changes influencing the intermediate host-parasite relationship. In addition, international travelling activities of domestic dogs/cats throughout South America significantly increased in the last years, posing an enhanced risk of parasite import and transmission to previously non-endemic areas as already reported for Europe [20]. Furthermore, the population dynamics of gastropods are strongly affected by a variety of abiotic factors such as temperature and humidity [31]. Taking into account that terrestrial snails/slugs play a crucial role in the life-cycle of A. vasorum and A. abstrusus [21], an improvement of environmental conditions for gastropods will promote an increased occurrence of aelurostrongylosis and angiostrongylosis in new geographical areas as postulated elsewhere [24]. In addition, wildlife reservoirs, such as red foxes (Vulpes vulpes), crab-eating foxes (Cerdocyon thous), coyotes (Canis latrans), bush dogs (Speothos venaticus) and a wide spectrum of wild felid species in South America, request further consideration for the better understanding of the epidemiology. As such, the spread of foxes from sylvatic into suburban/urban areas is a well-known phenomenon in many geographical areas [32]. This 'fox urbanization' can obviously contribute to the import of infectious parasitic stages to domestic dog habitats as recently demonstrated for central Europe [33]. Besides, also wild felids might become urbanized in South American tropical/subtropical cities with vast forested park areas, thus possibly contributing to the spread of feline aelurostrongylosis.

The purpose of this review is to summarize currently available data on the epidemiological situation of $A$. vasorum and $A$. abstrusus infections in dogs, cats and wildlife animals in South America. Given that these parasites indeed occur in several countries of this continent and therefore should be considered as differential 


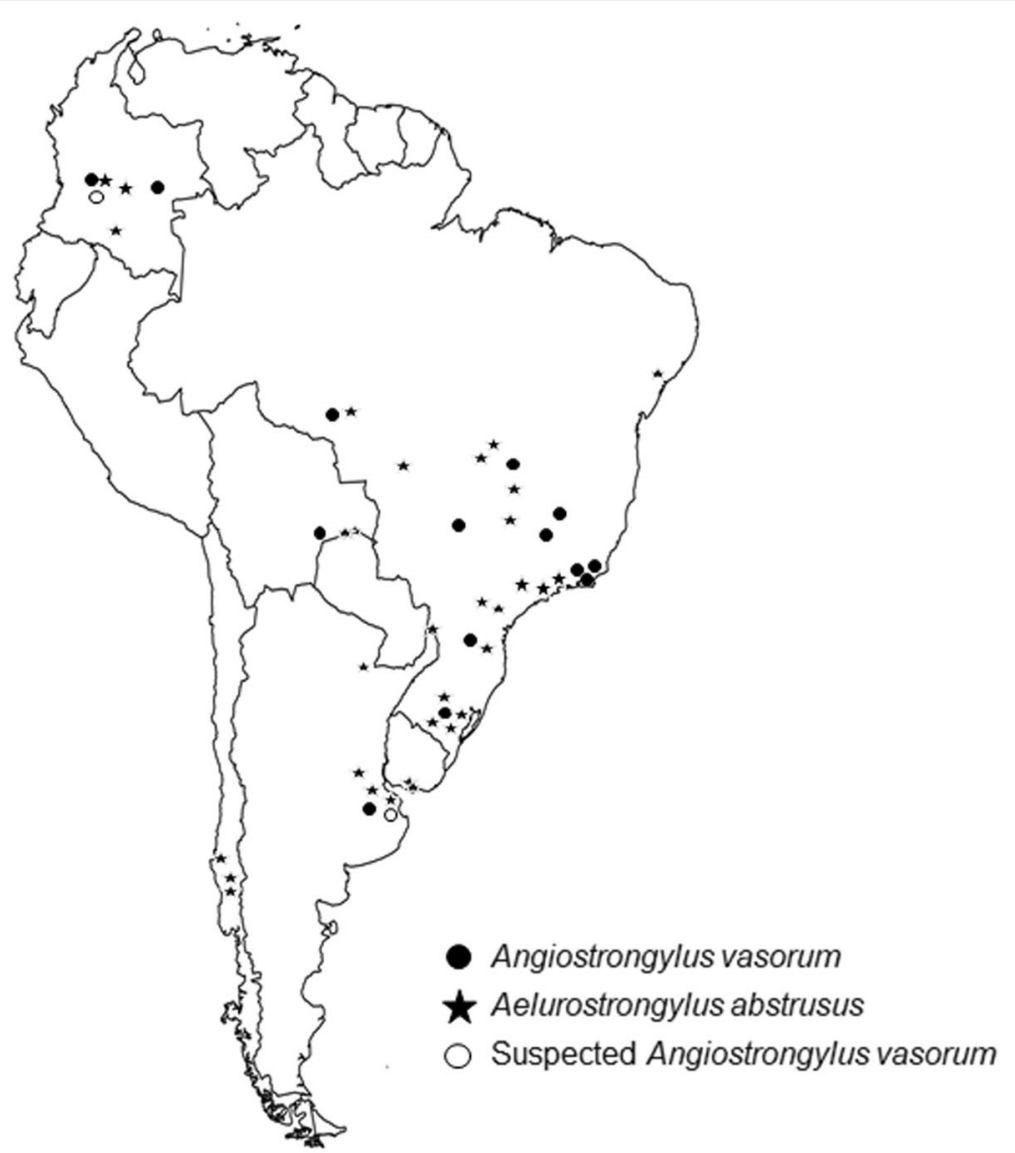

Fig. 1 Reports of natural occurring infections of Angiostrongylus vasorum and Aelurostrongylus abstrusus in South America

diagnoses in cases of canine cardiopulmonary/feline respiratory disease, the Baermann funnel technique should be included in routine diagnosis. Therefore, important informative aspects, such as the principles of the Baermann funnel technique, larval morphological characteristics and clinical signs are reviewed to encourage veterinarian surgeons and parasitologists to start investigations on these neglected diseases. Finally, novel diagnostic tools, such as serological and molecular approaches, are described briefly to stimulate future large-scale epidemiological surveys on lungworm infections, not only in domestic but also in wildlife animals of South America.

\section{Canine angiostrongylosis in South America}

Angiostrongylus vasorum (Baillet, 1866), also known as 'French heartworm', is a parasite of domestic dogs and wild species of the family Canidae, including foxes [34], coyotes [21] and wolves [35, 36] amongst others. Furthermore, this nematode has been reported to occur in other closely related carnivore species, such as mustelids and the red panda (Ailurus fulgens) [21]. Experimentally, the Nile rat (Arvicanthis niloticus) proved a suitable final host [37].
Angiostrongylus vasorum shows a rather patchy geographical distribution worldwide $[4,6,12,38-40]$ and its geographical spread and infection incidence are considered as increasing in the recent years $[2,41]$. A broad range of terrestrial snail and slug intermediate host species (e.g. Arion ater, A. rufus, A. lusitanicus, A.fulica, A distinctus, A. hortensis, Limax maximus, Helix aspersa and Tandonia sowerbyi) [42-45] are infected by L1 either by ingestion while feeding on faeces or by active penetration through the gastropod epidermis [34]. Merely experimentally, the common frog (Rana temporaria) and the domestic chicken (Gallus gallus) were demonstrated as paratenic hosts for $A$. vasorum [46, 47]. Within the definitive host, adult nematodes mainly reside in the right heart and pulmonary arteries. Adult fertilized females produce eggs which embryonate and hatch within the pulmonary capillaries where L1 penetrate into the alveoli [2], migrate into the trachea, larynx, buccal cavity, are swallowed and finally shed through faeces into the environment.

Canine angiostrongylosis ranges from subclinical cases to severe cardiopulmonary and neurological disorders or coagulopathies besides inducing nonspecific clinical signs [48]. Even fatal infections are frequently reported 
[48]. Historically, Angiostrongylus-like nematodes in dogs and foxes have been denominated as A. vasorum in Europe and as Haemostrongylus raillieti, Angiostrongylus raillieti or Angiocaulus raillieti in Brazil [49-51]. Based on morphological and molecular characteristics, a recent taxonomic revision proposed to amalgamate all these species into one single parasite species, namely $A$. vasorum $[41,51]$. However, genetic variations of European and Brazilian A. vasorum isolates suggested these isolates as separate cryptic species [41] but further investigations are needed to clarify the final taxonomy. Nonetheless, solving this taxonomic question requires a much larger sample size and the inclusion of additional isolates from different South American countries into genomic analyses, as previously suggested [41].

In Brazil, A. raillieti (syn. of $A$. vasorum) was reported in South American coati (Nasua nasua) and another Angiostrongylus sp. was described in the Tayra (Eira barbara). In both wild mammal species, adult parasites were found in the lungs, heart and pulmonary arteries [51, 52]. Based on the specific cardiopulmonary localization and the historical confusion on the nomenclature, we here refer to these reported parasites as $A$. vasorum. Future research on these and other wildlife species is therefore mandatory to elucidate the natural definitive host spectrum of $A$. vasorum in a geographical region to be considered as mega-biodiverse as it is the South America subcontinent [53].

As the first South American report, A. vasorum was found in the right ventricle and pulmonary arteries of the crab-eating fox C. thous (Linnaeus, 1766) in Rio de Janeiro, Brazil [49]. Thereafter, natural A. vasorum infections were reported to occur in domestic dogs in Rio Grande do Sul, Brazil and in the crab-eating fox in Colombia [13]. Later on, more cases of A. vasorum-infected crab-eating foxes were described in other Brazilian regions, such as Rio de Janeiro [54], Paraná [55] and Minas Gerais [56, 57]. Additionally, in Minas Gerais A. vasorum was found as parasitizing hoary foxes (Dusicyon vetulus) (Lund, 1842) (syn. Pseudoalopex or Lycalopex vetulus) [12]. As also reported for North American free-ranging red foxes (V. vulpes) [38], a rather high $A$. vasorum prevalence of up to $50 \%$ was detected in Brazilian crab-eating foxes [57] (Table 1). Overall, the sum of these data indicates a broad distribution of A. vasorum in wildlife fox populations in South America which will contribute to the parasite propagation and the sylvatic life-cycle maintenance as already reported for Europe [57].

Unfortunately, there also exist ambiguous reports on A. vasorum or Filaroides osleri canid infections in South America lacking proper morphological diagnosis $[58,59]$. One of these reports came from Argentina and included the coprological diagnosis 'lungworm larvae' for two domestic dogs without further characterization
[58]. Another report was from Colombia, where a lethal infection of a crab-eating fox was described and diagnosed as lungworm infection based on histopathological findings of the lungs showing parasitic structures which resembled metastrongyloid parasites [59]. Based on the uncertain diagnosis of these two studies, it seems that more detailed research and instructions for veterinarians, pathologists and parasitologists in South America are required. For more detailed data on biology, epidemiology, diagnostic techniques, clinical features as well as anthelminthic treatments the following reviews on canine angiostrongylosis are recommended: Koch \& Willesen [21], Helm et al. [44], Schnyder et al. [18] and Traversa \& Guglielmini [2].

\section{Feline aelurostrongylosis in South America}

Aelurostrongylus abstrusus (Railliet, 1898) infections are distributed worldwide [2, 19]. This parasite represents one of the most important etiological parasitic agents of respiratory alterations in domestic and wild felids [60, 61]. Clinical manifestations of feline aelurostrongylosis range widely from subclinical to a variety of respiratory signs such as dyspnoea, open-mouthed abdominal breathing, coughing, wheezing, sneezing and mucopurulent nasal discharge. Especially in cases of high-dose infections this parasitosis might have a clinical significance [62]. Analogous to A. vasorum, A. abstrusus has an indirect life-cycle involving a variety of terrestrial gastropods as intermediate hosts (i.e. A. lusitanicus, $L$. maximus [45], A. fulica [24, 45], $H$. aspersa [63]). Additionally, paratenic hosts such as rodents, frogs, lizards, snakes or birds are known to be involved in parasite lifecycle $[60,64]$. In contrast to $A$. vasorum, adult stages of $A$. abstrusus reside in the terminal respiratory bronchioles, alveolar ducts and pulmonary alveoli, where the females produce eggs, which embryonate and hatch within the pulmonary ducts and alveoli [62].

Regarding the presence of $A$. abstrusus infections in South America, there are reports in domestic and wildlife felids from Uruguay [65, 66], Argentina [67, 68], Brazil [15, 69-76], Chile [77-80], Colombia [14, 16, 81] and Bolivia [82] (see Table 2 and Fig. 1). The first report ever on an $A$. abstrusus infection in a cat from South America came from Uruguay in the year 1942 [65]. In 1953, Trein [83] reported 40 cases out of 102 analysed domestic cats which had been submitted to necropsy in Rio Grande do Sul, Brazil. Thereafter, a prevalence of $8.6 \%$ was estimated via necropsy in cats from Montevideo during the period 1958-1960 [84]. During the 1970s and 1980s, domestic feline aelurostrongylosis was reported in Chile [77-79], Brazil [70] and Argentina [68]. In the 1990s, more reports on feline aelurostrongylosis came from Argentina and Brazil [71, 85, 86].

The report on the highest altitude so far, referred to an incidentally diagnosed $A$. abstrusus infection in a cat 
Table 2 Reports on Aelurostrongylus abstrusus infections in definitive and intermediate hosts

\begin{tabular}{|c|c|c|c|}
\hline & Geographical location & Prevalence/no. of cases & Reference \\
\hline \multicolumn{4}{|l|}{ Definitive host species } \\
\hline Felis catus & Montevideo, Uruguay & 1 case & Bacigalupo et al., 1942 [65] \\
\hline Felis catus & Rio Grande do Sul, Brazil & $40 / 102$ & Trein, 1953 [83] \\
\hline Felis catus & Rio de Janeiro, Brazil & na & Langenegger and Lanzieri, 1963 [69] \\
\hline Felis catus & Montevideo, Uruguay & $8.6 \%$ & Esteves et al., 1961 [84] \\
\hline Felis catus & Chile & 1 case & Gonzalez \& Torres, 1971 [77] \\
\hline Felis catus & São Paulo, Brazil & na & Campedelli-Filho, 1972 [70] \\
\hline Felis catus & Valdivia, Chile & na & Torres et al., 1972 [78] \\
\hline Felis catus & Sâo Paulo, Brazil & $8.5 \%$ & Fenerich et al., 1975 [144] \\
\hline Felis catus & Valdivia, Chile & na & Bonilla-Zepeda, 1980 [79] \\
\hline Felis catus & La Plata, and Buenos Aires Argentina & $24.3 \%, 30.0 \%$ & Idiart et al., 1986 [68] \\
\hline Felis catus & Corrientes, Argentina & $30 \%$ & Martinez et al., 1990 [85] \\
\hline Felis catus & Rosario, Argentina & na & Schiaffi et al., 1995 [86] \\
\hline Felis catus & Santa Maria, Brazil & na & Headley \& Conrado, 1997 [71] \\
\hline $\begin{array}{l}\text { Puma yagouaroundi } \\
\text { Leopardus geoffroyi }\end{array}$ & Mato Grosso do Sul, Brazil & na & Noronha et al., 2002 [99] \\
\hline Felis catus & Bogota, Colombia & 1 case & Salamanca, 2003 [14] \\
\hline Felis catus & Uberlândia, Brazil & $18 \%$ & Mundim et al., 2004 [72] \\
\hline Felis catus & Santa Maria, Brazil & $\begin{array}{l}5.9-25 \% \\
\text { (mean 18.6\%, } \\
\text { 1987-1996) }\end{array}$ & Headley, 2005 [73] \\
\hline Felis catus & Buenos Aires, Argentina & $2.6 \%$ & Sommerfelt et al., 2006 [67] \\
\hline Leopardus pardalis & Bolivian Chaco & 5 cases & Fiorello et al., 2006 [82] \\
\hline Leopardus geoffroyi & & 3 cases & \\
\hline F.catus domesticus & Rio de Janeiro, Brazil & 1 case & Ferreira et al., 2007 [88] \\
\hline Felis catus & Quindío, Colombia & $0.21 \%(1 / 121)$ & Echeverry et al., 2012 [16] \\
\hline Felis catus & $\begin{array}{l}\text { Cuiaba and Várzea Grande, Matto } \\
\text { Grosso, Brazil }\end{array}$ & $1.3 \%$ & Ramos et al., 2013 [74] \\
\hline Felis catus & Montevideo, Uruguay & $2 / 8$ & Castro et al., 2013 [66] \\
\hline Felis catus & $\begin{array}{l}\text { Río Bueno y La Unión, Provincia del } \\
\text { Ranco, Chile }\end{array}$ & $20 / 200$ & Oyarzún-Cadagán, 2013 [80] \\
\hline Felis catus & Rio Grande do Sul, Brazil & $29.5 \%$ & Ehlers et al., 2013 [87] \\
\hline Felis catus & Buenos Aires, Argentina & $35.3 \%(6 / 17)$ & Cardillo et al., 2014 [91] \\
\hline $\begin{array}{l}\text { Leopardus wiedii, } \\
\text { Leopardus tigrinus }\end{array}$ & $\begin{array}{l}\text { Natural park De Trê Barras, Três Barras, } \\
\text { Brazil }\end{array}$ & $38.1 \%, 35.7 \%$ & Kusma et al., 2015 [15] \\
\hline Leopardus colocolo & Rio Grande do Sul, Brazil & 1 case & Gressler et al., 2016 [75] \\
\hline Felis catus & Rio Grande do Sul, Brazil & 22/2036 (1998-2005) & Pereira et al., 2017 [76] \\
\hline Felis catus & Caquetá, Colombia & 1 case & Sanchez-Rojas et al., 2017 [81] \\
\hline \multicolumn{4}{|c|}{ Intermediate host species } \\
\hline Achatina fulica & $\begin{array}{l}\text { Rio de Janeiro, Goiás, Espırito Santo, } \\
\text { Mato grosso, } \\
\text { Sergippe and São Paulo, Brazil }\end{array}$ & $5.57 \%(217 / 3806)$ & Thiengo et al, 2008 [90] \\
\hline Achatina fulica & São Paulo, Brazil & na & Ohlweiler et al., 2010 [145] \\
\hline Achatina fulica & Puerto Iguazu, Argentina & $2 \%$ & Valente et al., 2017 [24] \\
\hline Rumina decollate & Buenos Aires, Argentina & $80 \%(20 / 25)$ & Cardillo et al., 2014 [91] \\
\hline
\end{tabular}


from Bogota (Colombia) [14], which is located approximately 2600 meters above sea level (masl), proving the resilience of gastropod intermediate hosts. In 2012, another incidental case of feline aelurostrongylosis diagnosed via the Ritchie test came from Quindío (Colombia) during a parasitological survey in domestic cats, this region has an average altitude of 1458 masl, which supports the fact that $A$. abstrusus is adapted to South American mountainous zones [16]. It is worth noting that the Ritchie test only proves positive in cases of highly parasitized and larvae-shedding animals since it is not specific for the detection of L1 in faeces [14]. An epidemiological study on 50 feline necropsies from Uberlândia, Minas Gerais, Brazil, in 2004, revealed an $A$. abstrusus prevalence of $18 \%$ [72]. One year later, a retrospective study on $A$. abstrusus infections in domestic cats presented for routine necropsy during 1987-1996 at the Federal University of Santa Maria, Brazil, detected a prevalence of $5.9-25 \%$ [73]. In 2006, 2.6\% of stray cats from Buenos Aires, Argentina, were found positive for A. abstrusus using the faecal flotation technique [67]. The prevalence of A. abstrusus in cats from Porto Alegre, state of Rio Grande do Sul, Brazil remained equal to 29.5\% (24/88) during 2008 and 2009 [87].

In a survey in the metropolitan area of Cuiabá, Mato Grosso, Midwestern Brazil, cats revealed a prevalence of A. abstrusus of $1.3 \%$, diagnosed via necropsy [74]. A recent report came from Chile, where $10 \%$ of domestic cats from the cities Rio Bueno and La Union showed $A$. abstrusus infections via the Bearmann funnel technique [80]. Recently, A. abstrusus was found by necropsy in two out of eight investigated cats in Montevideo, Uruguay [66]. Additionally, a recent retrospective study during 1998-2015 identified 22 cats with A. abstrusus infections in Rio Grande do Sul, Brazil [76]. Finally, other case reports on infected domestic cats originated from Rio de Janeiro, Brazil (2007; [88]) and Caquetá, Colombia (2017; [81]).

In addition to domestic felines, $A$. abstrusus infections are also reported in several wildlife species acting as definitive hosts, such as jaguarondis (Puma yagouaroundi) and Geoffroy's cat (Leopardus geoffroyi), [89], margay ( $L$. wiedii), oncilla (L. tigrinus) [15] and Colo colo wildcats ( $L$. colocolo) [75]. Moreover, infected gastropod intermediate hosts have been reported in Brazil [90] and Argentina [24, 91] (see Table 2). As suitable intermediate host in South America, the terrestrial snail Rumina decollate has been reported in addition to the highly invasive African giant snail $A$. fulica. Interestingly, a rather high $A$. abstrusus prevalence was reported in $80 \%$ of $R$. decollate [91].

All above mentioned reports show that $A$. abstrusus cycles in both, sylvatic and urban areas. Therefore, it must be considered as differential diagnosis in cases of feline respiratory disease and in the management and conservation programmes on threatened wild felids in various regions of South America. For more details on the biology, epidemiology, pathophysiology, clinic, diagnosis and treatment options of feline aelurostrongylosis we recommend the recently published reviews of Elsheikha et al. [61] and Traversa \& Di Cesare [19].

\section{Diagnostic tools for the detection of $A$. vasorum and $A$. abstrusus infections Coprological diagnostics}

All coprological diagnostic methods described here share the limitation that they can be performed no earlier than seven weeks after the infection due to the parasites' prepatency [92].

In 1917, Baermann et al. [93] described a method to detect nematodes present in soil samples which was later on modified for lungworm larvae detection [94, 95]. This method is based on the hydrophilic and thermophilic behaviour of lungworm larvae [96]. Even though it is currently considered as a gold standard for the coprological diagnosis of feline and canine lungworm infections $[21,97]$, diagnosis may be hampered by the intermittent shedding of the larvae [98], a low viability of larvae [99], the seven week prepatency or scarce larval excretion in low-grade infections [100]. Therefore, the analysis of at least three samples from consecutive days is recommended by some authors [3,101-103]. Since the Baermann funnel technique is an easy method that does not require specific equipment, it can be carried out in any veterinarian clinic (Fig. 2a). For small-sized samples, a modification of this technique was recently developed by Conboy et al. [104] using $50 \mathrm{ml}$ screw top tubes as shown in Fig. 2b. Following a $12 \mathrm{~h}$ incubation, the larvae are here directly sedimented via centrifugation [104].

Following the sedimentation step, L1 of metastrongyloid lungworms of domestic carnivores are differentiated microscopically via morphological characteristics which are mainly based on size (length, width, body/oesophagus ratio) and distinct tail morphology as reported elsewhere [63, 105-108]. A general morphological characteristic shared by all metastrongyloid lungworm L1 is the nonrhabditiform oesophagus, which forms $1 / 3-1 / 2$ of the total larval length [4]. Considering the tail morphology, $A$. abstrusus L1 can be identified by its notched S-shaped tail (please see Fig. 3a), which is distinct from A. vasorum L1 possessing a sinus wave curve formed tail end with a dorsal spine (see Fig. 3b).

Another coproscopic technique for detection of lungworm larvae is the faecal smear [109], which is limited by a small sample size, includes no concentration step of parasitic stages, has a low sensitivity of $67 \%[2,110]$ and is therefore not recommended as a routine method. The same applies for the zinc sulphate-based flotation method. 


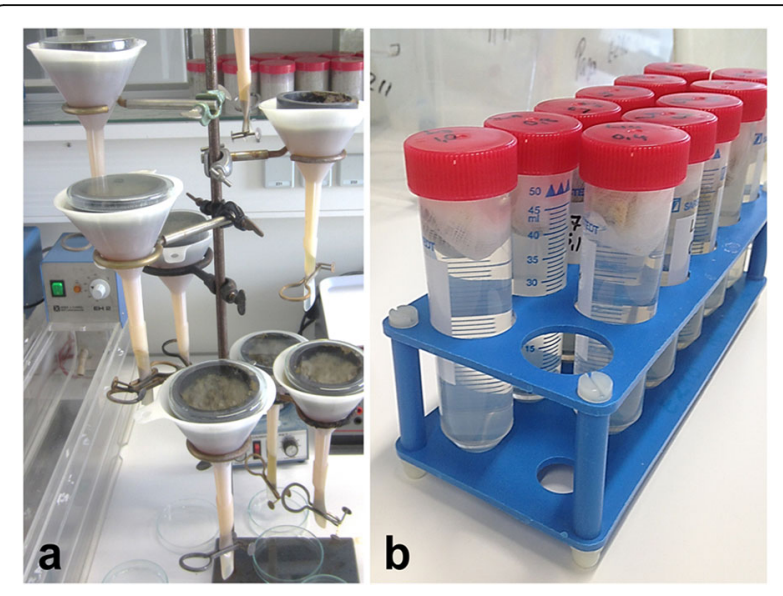

Fig. 2 Illustration of modified Baermann funnel techniques. This technique is considered as the gold standard for the diagnosis of lungworm infections in cat and dog faeces. a A household funnel is combined with a plastic tube of $10 \mathrm{~cm}$ length and closed by a metal tubing clamp. The funnel is filled with handwarm tap-water. Then a wire mesh screen ( $9 \mathrm{~cm}$ diameter, 0.20-0.25 mm aperture) has to be set in the top of the funnel. $\mathbf{b}$ Modification by Conboy et al. [104]: instead of a funnel, $50 \mathrm{ml}$ screw-top centrifuge tubes containing warm tap water are used. The faeces need to be placed in a double layer of cheesecloth, placed in the tube and the cap is screwed onto the tube catching a small part of the cheesecloth to keep it in place at the top at the tube. (Pictures taken by Malin K. Lange, Institute of Parasitology, Justus-Liebig-University Giessen)

In one survey, only 8/14 Baermann-positive fecal samples could be detected by this technique [111].

It is very important to emphasize that an accurate and definitive morphological identification of these parasites is a challenging process, which requires well-trained microscopists $[2,19]$. So far, there are 181 species in the

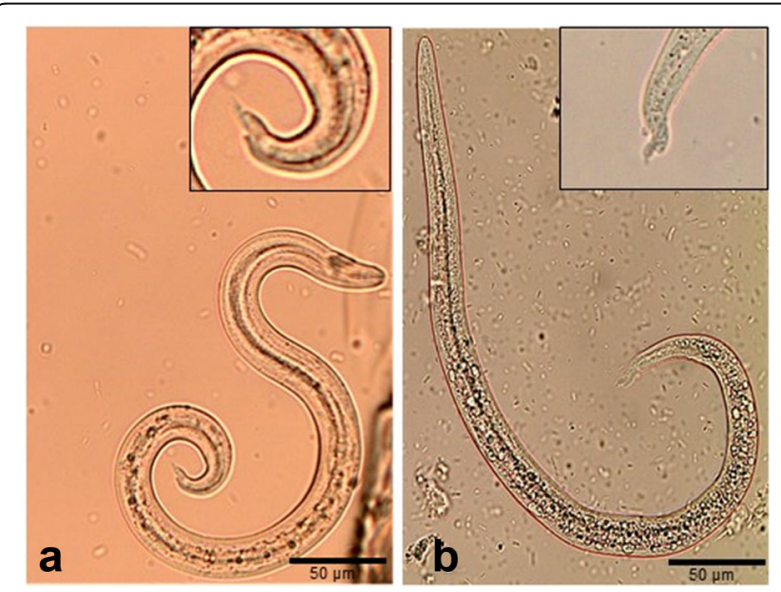

Fig. 3 Morphological characteristics of first-stage larvae of Angiostrongylus vasorum and Aelurostrongylus abstrusus. a The first-stage larvae of $A$. vasorum possess a sinus wave curve formed tail end with a dorsal spine. b The first-stage larvae of A. abstrusus can be identified by the notched S-shaped tail. (Pictures taken by Malin K. Lange, Institute of Parasitology, Justus-Liebig-University Giessen) superfamily Metastrongylidae, many of which with a similar life-cycle and morphology [11]. Other less common parasitic larvae could be detected by the Baermann technique and their morphological and morphometrical key features should be considered since they could be confused with the two species on which this review is focused (see Table 3). In the case of canid samples, it is relevant to consider possible detection of Crenosoma vulpis and Strongyloides stercolaris [4]. Strongyloides stercolaris is spread worldwide [112], while C. vulpis is endemic in European and North American red fox (Vulpes vulpes) $[30,38]$ populations and rare in dogs [3]. There is a unique report in South America, specifically in Chile (2013), where $1 \%(2 / 200)$ of the evaluated canine faecal samples resulted positive by the Baermann funnel test [80].

Concerning the microscopical identification of felid coprological samples, it is mandatory to take into account the possible findings of Troglostrongylus brevior, T. subcrenatus [19, 113], Oslerus rostratus [19, 114116], Strongyloides stercolaris [4], Angiostrongylus chabaudi [117], and Angiostrongylus felineus (recently discovered and described but only with adult stages in Puma yagouaroundi from Brazil; this is the reason why its L1 morphological description is lacking) [118]. Troglostrongylus brevior, T. subcrenatus, A. chabaudi and $O$. rostratus have been infrequently reported mainly in wild felids from Europe but not in South America [113, 116, 117]. Additionally, the existence of new metastrongyloid related species in a mega-biodiverse region such as South America could not be rejected and should be contemplated in future studies. Based on the prior observations, it is reasonable to consider the possibility of misdiagnosis in some reports of $A$. vasorum and $A$. abstrusus presented in this review, given that most of these studies were performed by microscopical identification, some of them many years ago, when surely the researchers were not aware of many above mentioned statements and species.

\section{Serological diagnostics}

As mentioned before, the gold standard technique for the detection of $A$. vasorum is the Baermann larval migration test [21, 97]. However, this method is constrained by the intermittent shedding of the larvae [98], the seven week prepatency and scarce larval excretion in low-intensity infections [100]. To improve the efficiency and accuracy of A. vasorum-related diagnostics, new methods were developed. Thus, enzyme-linked immunosorbent assay (ELISA) tests have been designed to detect circulating $A$. vasorum antigens in serum samples with a specificity ranging between $94-100 \%$ and a sensitivity between 42.9-95.7\% [99, 100, 119]. However, for some ELISAs non-specific reactions due to antigen- 
Table 3 Canid and felid cardiopulmonary nematodes: differential characters of fistt-stage larvae found by the Baermann funnel technique

\begin{tabular}{|c|c|c|c|}
\hline $\begin{array}{l}\text { Nematode (length } \times \text { width) } \\
(\mu \mathrm{m})\end{array}$ & Morphological keys & Final host & References \\
\hline \multirow{3}{*}{$\begin{array}{l}\text { Angiostrongylus vasorum } \\
(310-400 \times 14-16)\end{array}$} & A small cup as a cephalic button emerges on the oral extremity & \multirow[t]{3}{*}{ Canids } & \multirow[t]{3}{*}[1,2,4,146,147]{} \\
\hline & Oesophagus non-rhabditiform, $1 / 3-1 / 2$ the length of the larva & & \\
\hline & Tip with a dorsal spine and sinus wave curve & & \\
\hline \multirow{2}{*}{$\begin{array}{l}\text { Crenosoma vulpis }{ }^{a} \\
(240-310 \times 13)\end{array}$} & Oesophagus non-rhabditiform, $1 / 3-1 / 2$ the length of the larva & \multirow[t]{2}{*}{ Canids } & \multirow[t]{2}{*}[4,111,148,149]{} \\
\hline & $\begin{array}{l}\text { Tail, pointed and straight, without indentations and entirely } \\
\text { pointed }\end{array}$ & & \\
\hline \multirow[t]{3}{*}{$\begin{array}{l}\text { Aulerostrongylus abstrusus } \\
(300-415 \times 18-19)\end{array}$} & $\begin{array}{l}\text { Anterior extremity slender, with a short/terminal oral opening } \\
\text { leading into a narrow vestibule }\end{array}$ & \multirow[t]{3}{*}{ Felids } & \multirow[t]{3}{*}[4,63,150,151]{} \\
\hline & Oesophagus non-rhabditiform, $1 / 3-1 / 2$ the length of the larva & & \\
\hline & $\begin{array}{l}\text { Tail S-shaped, with visible dorsal kink, distinct deep dorsal, ventral } \\
\text { incisures, a terminal knob-like extremity }\end{array}$ & & \\
\hline \multirow[t]{3}{*}{$\begin{array}{l}\text { Troglostrongylus brevior } \\
(300-357 \times 16-19)\end{array}$} & $\begin{array}{l}\text { Anterior extremity clear and pointed, with a sub-terminal oral } \\
\text { opening }\end{array}$ & \multirow[t]{3}{*}{ Felids } & \multirow[t]{3}{*}[19,113,151-153]{} \\
\hline & Oesophagus non-rhabditiform, 1/3-1/2 the length of the larva & & \\
\hline & $\begin{array}{l}\text { Tail gradually tapered to dorsal incision, dividing the extremity } \\
\text { into two appendices (shallow ventral one, slender dorsal one). } \\
\text { S-shaped tail is not obvious, ending straight, gradually tapered }\end{array}$ & & \\
\hline \multirow{3}{*}{$\begin{array}{l}\text { Troglostrongylus subcrenatus } \\
(269-300 \times 14-19)\end{array}$} & Head pointed, oral opening subterminal (dorsal) & \multirow[t]{3}{*}{ Felids } & \multirow[t]{3}{*}[19,113,153]{} \\
\hline & Oesophagus non-rhabditiform, 1/3-1/2 the length of the larva & & \\
\hline & $\begin{array}{l}\text { Tail gradually tapered to the extremity with deep dorsal incisure } \\
\text { and shallower ventral incisure }\end{array}$ & & \\
\hline \multirow[t]{3}{*}{$\begin{array}{l}\text { Oslerus rostratus } \\
(335-412 \times 18-20)\end{array}$} & $\begin{array}{l}\text { Head rounded, with a central oral opening and a cylindrical } \\
\text { buccal capsule }\end{array}$ & \multirow[t]{3}{*}{ Felids } & \multirow[t]{3}{*}[1,4,151]{} \\
\hline & Oesophagus non-rhabditiform, 1/3-1/2 the length of the larva & & \\
\hline & $\begin{array}{l}\text { Tail slightly undulated, with a deep ventral notch (ending in } \\
\text { minuscule spine) and a shallow dorsal notch }\end{array}$ & & \\
\hline \multirow{3}{*}{$\begin{array}{l}\text { Angiostrongylus chabaudib } \\
(307-420 \times 14-16)\end{array}$} & Cephalic extremity rounded, with a terminal buccal opening & \multirow[t]{3}{*}{ Felids } & \multirow[t]{3}{*}[117,146,154,155]{} \\
\hline & Oesophagus non-rhabditiform, 1/3-1/2 the length of the larva & & \\
\hline & $\begin{array}{l}\text { Caudal extremity with a small dorsal spine and notch, ending in } \\
\text { a short sigmoid tail }\end{array}$ & & \\
\hline Angiostrongylus felineus ${ }^{c}$ & ? & Felids & [118] \\
\hline \multirow[t]{3}{*}{$\begin{array}{l}\text { Strongyloides stercoralis } \\
(150-390 \times 14-23)\end{array}$} & $\begin{array}{l}\text { Mouth with six lips, mouth-cavity rhabditiform, } 1 / 20-1 / 21 \text { of the } \\
\text { total length of oesophagus }\end{array}$ & \multirow[t]{3}{*}{ Felids and canids } & \multirow[t]{3}{*}[1,4,156]{} \\
\hline & $\begin{array}{l}\text { Oesophagus rhabditiform (corpus, isthmus, valvulated bulb), 1/4 } \\
\text { of the total length of the larva }\end{array}$ & & \\
\hline & Pointed and straight tail & & \\
\hline
\end{tabular}

${ }^{\mathrm{a}}$ Europe and North America; unique report in South America (1\% prevalence in dogs) in Chile [80]

${ }^{\mathrm{b}}$ Not reported in South America

'Described in 2013 in Puma yagouaroundi from Brazil, first-stage larvae have been not described (Viera et al. [118])

based cross-reactivity to other nematode infections were reported [92, 120]. Overall, A. vasorum antigen revealed as firstly detectable approximately five weeks after (experimental) infection and appeared to persists for a certain time period after elimination of the parasite [119]. Nevertheless, specific antigen detection may serve as a useful tool for treatment control, as previously proposed $[99,121]$ since antigen levels significantly decrease after treatment [119]. Thus, an absence of circulating antigens was observed in dogs treated with imidacloprid/ moxidectin at 4 or 32 days post-infection (pi) and in dogs treated at 88-92 days pi, circulatory antigens decreased within 13-34 days [119]. Recently, a rapid in situ assay (Angio Detect $^{\mathrm{Tm}}$ Test, IDEXX Laboratories, Westbrook, Maine, USA) was merchandized for the serological detection of circulating A. vasorum antigens. This assay showed $100 \%$ sensitivity at 14 weeks pi and and with the earliest positive reaction at 9 weeks pi. [99]. When compared to the Baermann funnel assay, the Angio Detect ${ }^{\mathrm{TM}}$ Test showed a sensitivity of $97.1 \%$ and a specificity of $98.9 \%$ 
[122]. Thus, this diagnostic test seems to be a useful diagnostic tool in a clinical setting.

Besides antigen detection, serological ELISA tests have been developed to detect specific antibodies raised against the parasite [122, 123]. However, antibody detection in a clinical context depends on the average life span of immunoglobulins and continued antigen stimulation [124]. In the early phase of infection specific antibodies can be detected while antigens are still not detectable [123]. Angiostrongylus vasorum-specific antibodies can be detected from 13 to 21 days after infection onwards persisting for up to nine weeks pi [125]. Thus, Cury et al. [97] detected A. vasorum-specific antibodies 14-28 days after experimental infection of dogs but humoral responses showed to be highly variable [126]. Serological tests for A. vasorum-specific antibody detection based on adult-, excretory/secretory (ES) antigens or L1 antigens showed a sensitivity of up to $85.7 \%$ and a specificity of $98.8 \%$ during prepatency [125]. However, Schucan et al. [125] found cross-reactions using adult somatic, adult ES antigens and L1 somatic antigen with sera of dogs infected with C. vulpis, Dirofilaria immitis, D. repens and Eucoleus aerophilus. When using monoclonal antibody-purified antigens, these cross-reactions were minimalized [125] and specificity was augmented [99, 119, 125, 127].

Angiostrongylus vasorum-specific antibodies can also be detected using the immunoblot (western blot) technique [97]. Although the sensitivity of western blots was higher than above mentioned antibody-ELISA [97], the former technique is only convenient for small sample sizes due to the large effort of this technique.

Both, antigen- and antibody-ELISAs were tested in a field study and compared to the Baermann funnel technique [123]. Thereby, the ELISAs principally confirmed Baermann-positive dogs and additionally detected nonpatent infections [123]. As suggested by Schnyder et al. [127], the detection of parasite-specific antigen indicates an actual infection status, while parasite-specific antibodies merely reflect earlier parasite exposure. Consequently, such cases in which both, circulating $A$. vasorum antigens and specific antibodies are detected are assumed as active $A$. vasorum infections while exclusive antibody detection indicates infections that were acquired in the past $[119,125]$. Nonetheless, it is important to note that antibody-seropositive dogs may also be free of parasites due to a self-curing process or treatment [125].

Regarding the serological diagnostics for A. abstrusus, these techniques are still in development and there are no commercially available serological tests for diagnosis of aelurostrongylosis [61]. Recently, an indirect fluorescent antibody test (IFAT) capable of detecting antibodies against $A$. abstrusus in sera from cats was developed and it showed to be promising in terms of sensitivity and specificity [128]. Furthermore, preliminary results suggest that the detection of antibodies using an ELISA might be a valuable tool for individual diagnosis and also for sero-epidemiological studies on feline aelurostrongylosis [61, 129].

Nonetheless, developing new diagnostic technologies with high sensitivity, specificity, availability and/or efficiency by means of improvement existing assays is necessary [61]. Presently, due to the lack of an optimal commercial serological diagnostic technique the Baermann method is recommended and could be employed for morphological detection of $A$. abstrusus infections which preferably should be confirmed by concurrent PCR. In the same way, larvae obtained from tracheal swabs or bronchoalveolar lavage could confirm the infection via PCR $[2,61]$

\section{Polymerase chain reaction (PCR)-based diagnostics}

Several studies used the PCR technique, mainly based on the second internal transcribed spacer (ITS2) region of ribosomal deoxyribonucleic acid (rDNA), in combination with sequencing of the amplified PCR product to confirm lungworm infections in dogs and wild carnivores [92, 130-135]. Using this molecular technique, different types of samples such as blood, faeces and mucosal smears or even intermediate hosts have successfully been used [132, 135]. However, the sensitivity and reliability of real-time PCR using ITS2 was dependent on the type of sample tested with blood being superior to faeces and pharyngeal or tracheal swabs regarding A. vasorum [92, 135, 136]. Houpin et al. [137] described a novel nested PCR- restriction fragment length (PCR-RFLP) [based on 185 ribosomal ribonucleic acid (rRNA)] for the detection and identification of canine lungworms with a sensitivity of $69.5 \%$. Copro-PCRbased analyses may also be useful in cases of Baermann funnel technique failure due to morphologically altered or less motile A. vasorum L1 [121]. However, false negative results in PCR-based analyses were reported depending on quality of the sample and amount of sample used for DNA extraction [92]. Therefore, PCR-based diagnostic techniques for detection of $A$. vasorum are considered less sensitive than ELISA and the Baermann funnel technique [92]. Nevertheless, PCR-based tools developed for the diagnosis of $A$. abstrusus infections showed a specificity of $100 \%$ and a sensitivity of $~ 97 \%$ [138]. In addition, an ITS2-based duplex PCR was developed to discriminate between A. abstrusus and $T$. brevior (a closely related lungworm parasite species) infections in a single cat [139]. Most recently, a triplex semi-nested PCR for the simultaneous detection of $A$. abstrusus, T. brevior and A. chabaudi (a rare cardiopulmonary nematode of wild felids) DNA was published [140]. 
Overall, since these novel molecular diagnostic tools have proven successful and effective for the diagnosis of canine angiostrongylosis and feline aelurostrongylosis thereby partially overcoming limitations of classical diagnostic methods, they may be useful to perform large-scale epidemiological surveys. However, the rather high costs of this molecular technique should also be taken into account, especially in poorer regions of South America.

\section{Conclusions}

Considering the wide distribution of canine angiostrongylosis and feline aelurostrongylosis in South America, it is of great interest that small and wildlife practice clinicians consider these infections (and the less common species such as $C$. vulpis, T. brevior, T. subrenatus, $A$. chabaudi, A. felineus and O. rostratus) as differential diagnosis in the case of cardiopulmonary disorders. Here, the implementation of routinely applied tools of diagnostics, such as the Baermann funnel technique, parasitological dissection, PCR and/or serology is essential for South America regions since correct diagnosis of infections will significantly contribute to an improved knowledge on the current epidemiological situation of these neglected parasitoses. Phylogenetic studies are also pending to evaluate if $A$. vasorum from South America actually represents a distinct genotype or species. Epidemiological surveys in domestic and wild canid and felids as well as paratenic- and intermediate-hosts with an accurate molecular characterization are required. Additionally, the impact of climatic factors (e.g. altitude, temperature, annual precipitation, relative humidity and biogeographical region) on host-parasite and parasiteintermediate host interactions and the spread of these parasites into non-endemic regions are relevant topics to be considered in future investigations in one of the most biodiverse regions of the planet.

\section{Abbreviations}

ELISA: enzyme-linked immunosorbent assay; ITS2: second internal transcribed spacer; L1: first-stage larvae; PCR: polymerase chain reaction; PCR-RFLP: polymerase chain reaction - restriction fragment length polymorphism; rDNA: ribosomal deoxyribonucleic acid; RNA: ribonucleic acid; rRNA: ribosomal ribonucleic acid

\section{Acknowledgements}

We are particularly grateful to the anonymous reviewers and to Dr David Villar (Veterinary Medicine School, University of Antioquia, Colombia) for their valuable advice and suggestions for this review.

\section{Funding}

Malin Katharina Lange was financially supported by the Hilde and Ewald Berge foundation.

Availability of data and materials Not applicable.
Authors' contributions

FPT, MKL, JJCC and CH wrote the manuscript. CH and AT revised the manuscript. All authors read and approved the final manuscript.

Ethics approval and consent to participate

Not applicable.

Consent for publication

Not applicable.

Competing interests

The authors declare that they have no competing interests.

\section{Publisher's Note}

Springer Nature remains neutral with regard to jurisdictional claims in published maps and institutional affiliations.

Received: 22 November 2017 Accepted: 4 March 2018

Published online: 27 March 2018

\section{References}

1. Conboy G. Helminth parasites of the canine and feline respiratory tract. Vet Clin North Am Small Anim Pract. 2009;39(6):1109-26.

2. Traversa D, Guglielmini C. Feline aelurostrongylosis and canine angiostrongylosis: a challenging diagnosis for two emerging verminous pneumonia infections. Vet Parasitol. 2008;157(3-4):163-74.

3. Taubert A, Pantchev N, Vrhovec MG, Bauer C, Hermosilla C. Lungworm infections (Angiostrongylus vasorum, Crenosoma vulpis, Aelurostrongylus abstrusus) in dogs and cats in Germany and Denmark in 2003-2007. Vet Parasitol. 2009;159(2):175-80.

4. Traversa D, Di Cesare A, Conboy G. Canine and feline cardiopulmonary parasitic nematodes in Europe: emerging and underestimated. Parasit Vectors. 2010;3:62.

5. Conboy GA. Canine angiostrongylosis: the French heartworm: an emerging threat in North America. Vet Parasitol. 2011:176(4):382-9.

6. Kistler WM, Brown JD, Allison AB, Nemeth NM, Yabsley MJ. First report of Angiostrongylus vasorum and Hepatozoon from a red fox (Vulpes vulpes) from West Virginia, USA. Vet Parasitol. 2014;200(1-2):216-20.

7. Helm J, Roberts L, Jefferies R, Shaw SE, Morgan ER. Epidemiological survey of Angiostrongylus vasorum in dogs and slugs around a new endemic focus in Scotland. Vet Rec. 2015;177(2):46.

8. Jolly S, Poncelet L, Lempereur L, Caron Y, Bayrou C, Cassart D, et al. First report of a fatal autochthonous canine Angiostrongylus vasorum infection in Belgium. Parasitol Int. 2015;64(1):97-9.

9. Nabais J, Alho AM, Gomes L, Ferreira da Silva J, Nunes T, Vicente G, et al. Aelurostrongylus abstrusus in cats and Angiostrongylus vasorum in dogs from Lisbon, Portugal. Acta Parasitol Portug. 2014;20(1/2):35-40.

10. Payo-Puente P, Botelho-Dinis M, Carvaja Uruena AM, Payo-Puente M, Gonzalo-Orden JM, Rojo-Vazquez FA. Prevalence study of the lungworm Aelurostrongylus abstrusus in stray cats of Portugal. J Feline Med Surg. 2008; 10(3):242-6.

11. Spratt DM. Species of Angiostrongylus (Nematoda: Metastrongyloidea) in wildlife: a review. Int J Parasitol Parasites Wildl. 2015;4(2):178-89.

12. Lima W, Guimaraes M, Lemos I. Occurrence of Angiostrongylus vasorum in the lungs of the Brazilian fox Dusicyon vetulus. J Helminthol. 1994;68(1):87.

13. Gonçalves P. Angiostrongylus vasorum (Baillet, 1866) novo parasito do cão no Rio Grande do Sul (Brasil) - Nematoda, Metastrongyloidea. Rev Fac Agron Vet. 1961;:3:35-40.

14. Salamanca J, Gil B, Cortés J. Parasitosis pulmonar por Aelurostrongylus abstrusus en un felino. Rev Fac Med Vet Zoo. 2003;50(2):30-4.

15. Kusma SC, Wrublewski DM, Teixeira VN, Holdefer DR. Parasitos intestinais de Leopardus wiedii e Leopardus tigrinus (Felidae) da Floresta Nacional De Três Barras, sc. Luminária. 2015;17(01):82-95.

16. Echeverry DM, Giraldo MI, Castaño JC. Prevalence of intestinal helminths in cats in Quindío, Colombia. Biomédica. 2012;32(3):430-6.

17. Otranto D, Cantacessi C, Dantas-Torres F, Brianti E, Pfeffer M, Genchi C, et al. The role of wild canids and felids in spreading parasites to dogs and cats in Europe. Part II: Helminths and arthropods. Vet Parasitol. 2015;213(1):24-37.

18. Schnyder M, Fahrion A, Riond B, Ossent P, Webster P, Kranjc A, et al. Clinical, laboratory and pathological findings in dogs experimentally infected with Angiostrongylus vasorum. Parasitol Res. 2010;107(6):1471-80. 
19. Traversa D, Di Cesare A. Diagnosis and management of lungworm infections in cats: cornerstones, dilemmas and new avenues. J Feline Med Surg. 2016;18(1):7-20.

20. Maksimov P, Hermosilla C, Taubert A, Staubach C, Sauter-Louis C, Conraths FJ, et al. GIS-supported epidemiological analysis on canine Angiostrongylus vasorum and Crenosoma vulpis infections in Germany. Parasit Vectors. 2017;10:108.

21. Koch J, Willesen JL. Canine pulmonary angiostrongylosis: an update. Vet J. 2009;179(3):348-59.

22. Sauerländer R, Eckert J. Die Achatschnecke (Achatina fulica) als experimenteller Zwischenwirt für Angiostrongylus vasorum (Nematoda). Z Parasitenk. 1974:44(1):59-72.

23. Jeżewski W, Buńkowska-Gawlik K, Hildebrand J, Perec-Matysiak A, Laskowski Z. Intermediate and paratenic hosts in the life cycle of Aelurostrongylus abstrusus in natural environment. Vet Parasitol. 2013; 198(3):401-5.

24. Valente R, Diaz JI, Salomón OD, Navone GT. Natural infection of the feline lungworm Aelurostrongylus abstrusus in the invasive snail Achatina fulica from Argentina. Vet Parasitol. 2017;235:17-9.

25. Pavanelli GC, Yamaguchi MU, Calaça EA, Oda FH. Scientometrics of zoonoses transmitted by the giant African snail Achatina fulica Bowdich, 1822. Rev Inst Med Trop Sao Paulo. 2017:59:e15.

26. Vogler RE, Beltramino AA, Sede MM, Gregoric DEG, Núñez V, Rumi A. The giant African snail, Achatina fulica (Gastropoda: Achatinidae): using bioclimatic models to identify South American areas susceptible to invasion. Am Malacol Bul. 2013;31(1):39-50.

27. Raut SK, Barker GM. Achatina fulica Bowdich and other Achatinidae as pests in tropical agriculture. In: Barker GM, editor. Molluscs as crop pests. Wallingford: CABI Publishing; 2002. p. 55-114.

28. Thiengo SC, Faraco FA, Salgado NC, Cowie RH, Fernandez MA. Rapid spread of an invasive snail in South America: the giant African snail, Achatina fulica in Brasil. Biol Invasions. 2007;9(6):693.

29. Hartwig V, Schulze C, Barutzki D, Schaper R, Daugschies A, Dyachenko V. Detection of Angiostrongylus vasorum in red foxes (Vulpes vulpes) from Brandenburg, Germany. Parasitol Res. 2015;114(Suppl. 1):S185-92.

30. Taylor CS, Garcia Gato R, Learmount J, Aziz NA, Montgomery C, Rose H, et al. Increased prevalence and geographic spread of the cardiopulmonary nematode Angiostrongylus vasorum in fox populations in Great Britain. Parasitology. 2015;142(9):1190-5.

31. Jenkins EJ, Kutz SJ, Hoberg EP, Polley L. Bionomics of larvae of Parelaphostrongylus odocoilei (Nematoda: Protostrongylidae) in experimentally infected gastropod intermediate hosts. J Parasitol. 2006:92(2):298-305

32. Delgado, Vélez CA. Adiciones al atropellamiento vehicular de mamíferos en la vía de El Escobero, Envigado (Antioquia), Colombia. Revista ElA. 2014; 11(22):147-53.

33. Schnyder M. Slugs and Angiostrongylus vasorum - how much do we know? Vet Rec. 2015;177(2):44-5.

34. Morgan ER, Shaw SE, Brennan SF, De Waal TD, Jones BR, Mulcahy G. Angiostrongy/us vasorum: a real heartbreaker. Trends Parasitol. 2005; 21(2):49-51.

35. Segovia J, Torres J, Miquel J, Llaneza L, Feliu C. Helminths in the wolf, Canis lupus, from north-western Spain. J Helminthol. 2001;75(2):183-92.

36. Hermosilla C, Kleinertz S, Silva LMR, Hirzmann J, Huber D, Kusak J, et al. Protozoan and helminth parasite fauna of free-living Croatian wild wolves (Canis lupus) analyzed by scat collection. Vet Parasitol. 2017;233:14-9.

37. Bolt G, Monrad J, Koch J, Jensen A. Canine angiostrongylosis: a review. Vet Rec. 1994;135(19):447-52

38. Jeffery RA, Lankester MW, McGrath MJ, Whitney HG. Angiostrongylus vasorum and Crenosoma vulpis in red foxes (Vulpes vulpes) in Newfoundland, Canada. Can J Zool. 2004;82(1):66-74.

39. Bwangamoi O. Angiostrongylus vasorum and other worms in dogs in Uganda. Vet Rec. 1972;91(11):267.

40. Bourque A, Whitney $\mathrm{H}$, Conboy $\mathrm{G}$. Angiostrongylus vasorum infection in a coyote (Canis latrans) from Newfoundland and Labrador, Canada. J Wildlife Dis. 2005;41(4):816-9.

41. Jefferies $R$, Shaw S, Viney M, Morgan E. Angiostrongylus vasorum from South America and Europe represent distinct lineages. Parasitology. 2009:136(1):107-15.

42. Patel Z, Gill AC, Fox MT, Hermosilla C, Backeljau T, Breugelmans K, et al. Molecular identification of novel intermediate host species of Angiostrongylus vasorum in Greater London. Parasitol Res. 2014;113(12):4363-9.
43. Ferdushy T, Kapel CM, Webster P, Al-Sabi MN, Gronvold J. The occurrence of Angiostrongylus vasorum in terrestrial slugs from forests and parks in the Copenhagen area, Denmark. J Helminthol. 2009;83(4):379-83.

44. Helm JR, Morgan ER, Jackson MW, Wotton P, Bell R. Canine angiostrongylosis: an emerging disease in Europe. J Vet Emerg Crit Care (San Antonio). 2010;20(1):98-109.

45. Lange MK, Penagos-Tabares F, Muñoz-Caro T, Gärtner U, Mejer H, Schaper R, et al. Gastropod-derived haemocyte extracellular traps entrap metastrongyloid larval stages of Angiostrongylus vasorum, Aelurostrongylus abstrusus and Troglostrongylus brevior. Parasit Vectors. 2017;10:50.

46. Bolt G, Monrad J, Frandsen F, Henriksen P, Dietz HH. The common frog (Rana temporaria) as a potential paratenic and intermediate host for Angiostrongylus vasorum. Parasitol Res. 1993:79:428-30.

47. Mozzer LR, Lima WS. Gallus gallus domesticus: paratenic host of Angiostrongylus vasorum. Vet Parasitol. 2015;207(1-2):81-4.

48. Di Cesare A, Traversa D. Canine angiostrongylosis: recent advances in diagnosis, prevention, and treatment. Vet Med. 2014;2014(5):181-92.

49. Travassos L. Nematódeos novos. Bol Biol S Paulo, Brazil. 1927;6:52-61.

50. Grisi L. Ocorrência de Angiocaulus raillieti (Travassos, 1927) comb. n. em Canis familiaris L. (Nematoda, Protostrongylidae). Rev Bras Biol. 1971; 31(1):27-32.

51. Costa J, de Araujo CH, Guimaraes M. Redescription of Angiostrongylus vasorum (Baillet, 1866) and systematic revision of species assigned to the genera Angiostrongylus Kamensky, 1905 and Angiocaulus Schulz, 1951. Rev Med Vet-Toulouse. 2003;154(1):9-16.

52. Vieira FM, Luque JL, Muniz-Pereira LC. Checklist of helminth parasites in wild carnivore mammals from Brazil. Zootaxa. 2008;1721:1-23.

53. de Oliveira TG, Mazim FD, Vieira OQ, Barnett AP, GdN S, Soares JB, et al. Nonvolant mammal megadiversity and conservation issues in a threatened central Amazonian hotspot in Brazil. Trop Conserv Sci. 2016;9(4):1-16.

54. Langenegger J, Langenegger A, Dacorso Filho P, Gouvea G. Ocorrência da infestação por Angiostrongylus vasorum em cães do Rio de Janeiro. In: Congreso Brasileiro de Medicina Veterinária $8^{\circ}$. Belo Horizonte. Anales Belo Horizonte UFMG. 1962: 246-247.

55. Giovannoni M, Fernandes BF, Kavinski LC. Angiostrongilose do cäo. Arq Biol Tecnol. 1985;28(4):601-4.

56. dos Santos LW, de Araujo CH, Guimaraes M, Leite A. Angiostrongylus vasorum (Baillet, 1866) Nematoda: Protostrongylidae, in dogs of Minas Gerais, Brazil. Mem Inst Oswaldo Cruz. 1985;80(2):233-5.

57. Duarte F, Vieira F, Louzada G, Bessa E, Souzalima S. Occurrence Angiostrongylus vasorum (Baillet, 1866) (Nematoda, Angiostrongylidae) in Cerdocyon thous Linnaeus, 1766 (Carnivora, Canidae) in Minas Gerais State Brazil. Arq Bras Med Vet Zoo. 2007:59(4):1086-8.

58. Venturini L, Boren J. Metastrongylosis de perros. Vet Argent. 1991;8:177-9.

59. Varela-Arias N, Toro-Mesa D, Caicedo-Martínez JA, Ospina-Chiriví J. Coinfección entre distemper canino y un verme pulmonar en un Cerdocyon thous en Estado Silvestre en el Municipio de Pereira. Mem Conf Interna Med Aprovech Fauna Silv Exót Conv. [SI]. 2014;10(2):145-59.

60. Scott D. Current knowledge of aelurostrongylosis in the cat. Literature review and case reports. Cornell Vet. 1973;63(3):483.

61. Elsheikha HM, Schnyder M, Traversa D, Di Cesare A, Wright I, Lacher DW. Updates on feline aelurostrongylosis and research priorities for the next decade. Parasit Vectors. 2016:9:389.

62. Traversa D, Lia RP, lorio R, Boari A, Paradies P, Capelli G, et al. Diagnosis and risk factors of Aelurostrongylus abstrusus (Nematoda, Strongylida) infection in cats from Italy. Vet Parasitol. 2008;153(1):182-6.

63. Giannelli A, Ramos RA, Annoscia G, Di Cesare A, Colella V, Brianti E, et al. Development of the feline lungworms Aelurostrongylus abstrusus and Troglostrongylus brevior in Helix aspersa snails. Parasitology. 2014;141(4):563-9.

64. Anderson RC. Nematode Parasites of Vertebrates. Their Development and Transmission. 2nd ed. Wallingford, Oxon (UK): CABI Publishing; 2000. p. 650

65. Bacigalupo J, Pou MC, Viera O, Matto J. Bronco-neumonía por Aelurostrongylus abstrusus (Railliet, 1898) en el Río de la Plata. Bol Mens Pol San Anim. 1942:26:283-92.

66. Castro O, Valledor S, Crampet A, Casás G. Aporte al conocimiento de los metazoos parásitos del gato doméstico en el Departamento de Montevideo, Uruguay. Veterinaria (Montevideo). 2013;49(190):28-37.

67. Sommerfelt I, Cardillo N, López C, Ribicich M, Gallo C, Franco A. Prevalence of Toxocara cati and other parasites in cats' faeces collected from the open spaces of public institutions: Buenos Aires, Argentina. Vet Parasitol. 2006; 140(3):296-301. 
68. Idiart J, Martín A, Venturini L, Ruager J. Neumonía por Aelurostrongylus abstrusus en gatos. Primeros hallazgos en el gran Buenos Aires y La Plata. Veterinaria Argent. 1986;23(3):229-37.

69. Langenegger J, Lanzieri P. Incidência e intensidade de infestação por helmintos em Felis catus domesticus do Rio de Janeiro. Veterinária. 1963; 16(18):77-89.

70. Campedelli-Filho O. Ocorrencia de broncopneumonia verminotica em gatos causada por Aelurostrongylus abstrusus (Railliet, 1898) no Estado de Sao Paulo (Nematoda: Protostrongylidae). Biologico. 1972;38(11):398-400.

71. Headley SA, Conrado LFI. Pneumonia verminótica por Aelurostrongylus abstrusus em gatos. J Integr Pesq, Extens E Ens. 1997;4:692.

72. Mundim T, Oliveira Júnior S, Rodrigues D, Cury M. Frequency of helminthes parasites in cats of Uberlândia, Minas Gerais. Arq Bras Med Vet Zoo. 2004; 56(4):562-3.

73. Headley SA. Aelurostrongylus abstrusus induced pneumonia in cats: pathological and epidemiological findings of 38 cases (1987-1996). SeminCienc Agrar. 2005;26(3):373-80

74. Ramos DGdS, Scheremeta RGAdC, Oliveira ACSd, Sinkoc AL, Pacheco RdC. Survey of helminth parasites of cats from the metropolitan area of Cuiabá, Mato Grosso, Brazil. Rev Bras Parasitol Vet. 2013;22(2):201-6.

75. Gressler LT, Noll JCG, ÍBd F, Monteiro SG. Multiparasitism in a wild cat (Leopardus colocolo) (Carnivora: Felidae) in southern Brazil. Rev Bras Parasitol V. 2016;25(3):374-7.

76. Pereira PR, Argenta FF, Rolim VM, de Oliveira EC, Sonne L, Pavarini SP, et al. Estudo retrospectivo de pneumonia por Aelurostrongylus abstrusus em gatos. Acta Sci Vet. 2017:45:1-8.

77. González H, Torres P. Aelurostrongylus abstrusus en el gato doméstico. Primera comunicación en Chile. Arch Med Vet. 1971;3:118-24.

78. Torres P, Hott A, Boehmwald H. Protozoos, helmintos y artropodos en gatos de la ciudad de Valdivia y su imporancia para el hombre. Arch Med Vet. 1972;4(2):20-9.

79. Bonilla-Zepeda C. Study of the helminth fauna of cats from Valdivia, Chile. Arch Med Vet. 1980;12(2):277.

80. Oyarzún-Cadagán JA. Pesquisa de nematodos pulmonares en perros y gatos de las ciudades de Río Bueno y La Unión, Provincia del Ranco, Chile: Universidad Austral De Chile Valdivia. 2013. http://cybertesis.uach.cl/tesis/ uach/2013/fvo.98p/doc/fvo.98p.pdf. Accessed 8 Mar 2018.

81. Sánchez-Rojas I, Cabrera-Gutiérrez E, Cuellar-Ramón J, Murcia-Bastidas C, SánchezManchola L, Sánchez-Monge E. Diagnóstico postmortem de Aelurostrongylus abstrusus (Railliet, 1898) en un felino mestizo: primer reporte en el municipio de Florencia, Departamento del Caquetá, Colombia. Rev Electrón Vet. 2017;18(5):1-9.

82. Fiorello CV, Robbins RG, Maffei L, Wade SE. Parasites of free-ranging small canids and felids in the Bolivian Chaco. J Zoo Wildlife Med. 2006;37(2):130-4.

83. Trein EJ. Lesões produzidas por Aelurostrongylus abstrusus (Railliet, 1898) no pulmão do gato doméstico. Porto Alegre: Oficinas gráficas da livraria Selbach: Universidade do Rio Grande do Sul; 1953.

84. Esteves $L$, Levratto $R$, Sobrero $T$. Estudio estadístico de la incidencia parasitaria en animales domésticos. An Fac Vet Uruguay. 1961;10:75-8.

85. Martínez A, Santa Cruz A, Lombardero O. Histopathological lesions in feline aelurostrongylosis. Rev Med Vet (Buenos Aires). 1990;71(6):260-4.

86. Schiaffi A, Bela M, Bola L, Peruzzo L. Aelurostrongylus abstrusus: Diagnostico en la ciudad de Rosario. Vet Arg. 1995;12(117):480-3.

87. Ehlers A, de Mattos MJT, Marques SMT. Prevalência de Aelurostrongylus abstrusus (Nematoda, Strongylida) em gatos de Porto Alegre, Rio Grande do Sul. Revista da FZVA. 2013;19(1):97-104.

88. Ferreira AMR, de Souza-Dantas LM, Labarthe N. Registro de um caso de Aelurostrongylus abstrusus (Railliet, 1898) em um gato doméstico no Rio de Janeiro, RJ. Braz J Vet Res Ani Sci. 2007;44(1):24-6.

89. Noronha D, Vicente JJ, Pinto RM. A survey of new host records for nematodes from mammals deposited in the Helminthological Collection of the Oswaldo Cruz Institute (CHIOC). Rev Bras Zool. 2002;19(3):945-9.

90. Thiengo SC, Fernandez MA, Torres EJ, Coelho PM, Lanfredi RM. First record of a nematode Metastrongyloidea (Aelurostrongylus abstrusus larvae) in Achatina (Lissachatina) fulica (Mollusca, Achatinidae) in Brazil. J Invertebr Pathol. 2008;98(1):34-9.

91. Cardillo N, Clemente A, Pasqualetti M, Borrás P, Rosa A, Ribicich M. First report of Aelurostrongylus abstrusus in domestic land snail Rumina decollata, in the Autonomous city of Buenos Aires. InVet. 2014;16(1):15-22.

92. Jefferies R, Morgan ER, Helm J, Robinson M, Shaw SE. Improved detection of canine Angiostrongylus vasorum infection using real-time PCR and indirect ELISA. Parasitol Res. 2011;109(6):1577-83.
93. Baermann G. A simple method for the detection of Ankylostomum (nematode) larvae in soil tests. In: Baermann G, editor. Mededelingen uit het Geneeskundig Laboratorium te Weltevreden. Batavia: Javasche Boekhandel \& Drukkerij; 1917. p. 41-7.

94. Rode B, Jørgensen RJ. Baermannization of Dictyocaulus spp. from faeces of cattle, sheep and donkeys. Vet Parasitol. 1989;30(3):205-11.

95. Jørgensen RJ, Ogbourne CP. Bovine dictyocauliasis: a review and annotated bibliography. Slough: Published on behalf of CIP by the Commonwealth Agricultural Bureaux; 1985. p. 104.

96. Barçante JM, Barcante TA, Dias SR, Vieira LQ, Lima WS, Negrao-Correa D. A method to obtain axenic Angiostrongylus vasorum first-stage larvae from dog feces. Parasitol Res. 2003;89(2):89-93.

97. Cury M, Guimarães M, Lima W, Vitor R. Western blot analysis of the humoral response of dogs experimentally infected with Angiostrongylus vasorum (Baillet, 1866). Vet Parasitol. 2002;106(1):83-7.

98. Oliveira-Junior SD, Barcante JM, Barcante TA, Dias SR, Lima WS. Larval output of infected and re-infected dogs with Angiostrongylus vasorum (Baillet, 1866) Kamensky, 1905. Vet Parasitol. 2006;141(1-2):101-6.

99. Schnyder M, Stebler K, Naucke TJ, Lorentz S, Deplazes P. Evaluation of a rapid device for serological in-clinic diagnosis of canine angiostrongylosis. Parasit Vectors. 2014;7:72.

100. Verzberger-Epshtein I, Markham R, Sheppard J, Stryhn H, Whitney H, Conboy $\mathrm{G}$. Serologic detection of Angiostrongylus vasorum infection in dogs. Vet Parasitol. 2008;151(1):53-60.

101. Willesen J, Møller J, Koch J, Jensen AL, Kristensen AT. Tidlig diagnostik af Angiostrongylus vasorum (fransk hjerteorm) og Crenosoma vulpis (rævens lungeorm) hos hunde er mulig ved hjælp af modifiseret Baermann test. Dansk Veterinærtidsskrift. 2004;87(17):6-10.

102. Barutzki D, Schaper R. Natural infections of Angiostrongylus vasorum and Crenosoma vulpis in dogs in Germany (2007-2009). Parasitol Res. 2009; 105(Suppl. 1):S39-48.

103. Paradies P, Schnyder M, Capogna A, Lia RP, Sasanelli M. Canine angiostrongylosis in naturally infected dogs: clinical approach and monitoring of infection after treatment. Sci World J. 2013;2013:8.

104. Conboy G, Guselle N, Schaper R. Spontaneous shedding of metastrongyloid third-stage larvae by experimentally infected Limax maximus. Parasitol Res. 2017;116(1):41-54.

105. Ash LR. Diagnostic morphology of the third-stage larvae of Angiostrongylus cantonensis, Angiostrongylus vasorum, Aelurostrongylus abstrusus, and Anafilaroides rostratus (Nematoda: Metastrongyloidea). J Parasitol. 1970;56(2):249-53.

106. Guilhon J, Cens B. Angiostrongylus vasorum (Baillet, 1866). Etude biologique et morphologique. Ann Parasit Hum Comp. 1973;48:567-96.

107. Di Cesare A, Crisi PE, Di Giulio E, Veronesi F, Frangipane di Regalbono A, Talone T, et al. Larval development of the feline lungworm Aelurostrongylus abstrusus in Helix aspersa. Parasitol Res. 2013;112(9):3101-8.

108. Wetzel R. Zur Biologie des Fuchslungenwurmes Crenosoma vulpis. Arch Wiss Prakt Tierheilk. 1940;75:445-50.

109. Ramsey I, Littlewood J, Dunn J, Herrtage M. Role of chronic disseminated intravascular coagulation in a case of canine angiostrongylosis. Vet Rec. 1996;138(15):360-3.

110. Humm K, Adamantos S. Is evaluation of a faecal smear a useful technique in the diagnosis of canine pulmonary angiostrongylosis? J Small Anim Pract. 2010;51(4):200-3.

111. Conboy G. Natural infections of Crenosoma vulpis and Angiostrongylus vasorum in dogs in Atlantic Canada and their treatment with milbemycin oxime. Vet Rec. 2004;155:16-8.

112. Schär F, Trostdorf U, Giardina F, Khieu V, Muth S, Marti H, et al. Strongyloides stercoralis: global distribution and risk factors. PLoS Negl Trop Dis. 2013;7(7):e2288.

113. Brianti E, Giannetto S, Dantas-Torres F, et al. Lungworms of the genus Troglostrongylus (Strongylida: Crenosomatidae): neglected parasites for domestic cats. Vet Parasitol. 2014;202:104-12.

114. Otranto, D. Diagnostic challenges and the unwritten stories of dog and cat parasites. Vet Parasitol. 2015; 212(1-2):54-61.

115. Juste RA, Garcia AL, Mencía L. Mixed infestation of a domestic cat by Aelurostrongylus abstrusus and Oslerus rostratus. Angew Parasitol. 1992;33:56-60

116. Brianti E, Gaglio G, Napoli E, Falsone L, Giannelli A, Annoscia G, et al. Feline lungworm Oslerus rostratus (Strongylida: Filaridae) in Italy: first case report and histopathological findings. Parasitol Res. 2014b;113:3853-7.

117. Giannelli A, Ramos RA, Annoscia G, Di Cesare A, Colella V, Brianti E, et al. Angiostrongylus chabaudi in felids: New findings and a review of the literature. Vet Parasitol. 2016;228:188-92. 
118. Vieira FM, Muniz-Pereira LC, de Souza LS, Neto AHM, Guimarães EV, Luque $J$ L. A new metastrongyloidean species (Nematoda) parasitizing pulmonary arteries of Puma (Herpailurus) yagouaroundi (É. Geoffroy, 1803) (Carnivora: Felidae) from Brazil. J Parasitol. 2013;99(2):327-31.

119. Schnyder M, Tanner I, Webster P, Barutzki D, Deplazes P. An ELISA for sensitive and specific detection of circulating antigen of Angiostrongylus vasorum in serum samples of naturally and experimentally infected dogs. Vet Parasitol. 2011;179(1-3):152-8.

120. Cury M, Lima W, Vitor R. Enzyme-linked immunosorbent assay (ELISA) for the diagnosis of Angiostrongylus vasorum (Baillet, 1866) infection in dogs. Revue Med Vet. 1996;147:525-30.

121. Elsheikha HM, Holmes SA, Wright I, Morgan ER, Lacher DW. Recent advances in the epidemiology, clinical and diagnostic features, and control of canine cardio-pulmonary angiostrongylosis. Vet Res. 2014;45(1):92.

122. Liu J, Schnyder M, Willesen JL, Potter A, Chandrashekar R. Performance of the Angio Detect ${ }^{T M}$ in-clinic test kit for detection of Angiostrongylus vasorum infection in dog samples from Europe. VPRSR. 2017;7:45-7.

123. Guardone L, Schnyder M, Macchioni F, Deplazes P, Magi M. Serological detection of circulating Angiostrongylus vasorum antigen and specific antibodies in dogs from central and northern Italy. Vet Parasitol. 2013;18(1):192-8.

124. Morgan E, Shaw S. Angiostrongylus vasorum infection in dogs: continuing spread and developments in diagnosis and treatment. J Small Anim Pract. 2010;51(12):616-21.

125. Schucan A, Schnyder M, Tanner I, Barutzki D, Traversa D, Deplazes P. Detection of specific antibodies in dogs infected with Angiostrongylus vasorum. Vet Parasitol. 2012;185(2):216-24.

126. Gillis-Germitsch N, Kapel C, Thamsborg SM, Deplazes P, Schnyder M. Hostspecific serological response to Angiostrongylus vasorum infection in red foxes (Vulpes vulpes): implications for parasite epidemiology. Parasitology. 2017:144(9):1144-53.

127. Schnyder M, Schaper R, Bilbrough G, Morgan ER, Deplazes P. Seroepidemiological survey for canine angiostrongylosis in dogs from Germany and the UK using combined detection of Angiostrongylus vasorum antigen and specific antibodies. Parasitology. 2013;140(11):1442-50.

128. Briggs KR, Yaros JP, Lucio-Foster A, Lee AC, Bowman DD. Detecting Aelurostrongylus abstrusus-specific lgG antibody using an immunofluorescence assay. J Feline Med Surg. 2013;15(12):1114-8.

129. Schnyder M. Prevalence of gastrointestinal and lung parasites in Swiss cats and first evaluations of ELISAs to detect antibodies against Aelurostrongylus abstrusus. Liverpool: Proceedings of the 25th International Conference of the World Association for the Advancement of Veterinary Parasitology; 2015. p. 225.

130. Caldeira RL, Carvalho OS, Mendonça CL, Graeff-Teixeira C, Silva MC, Ben R, et al. Molecular differentiation of Angiostrongylus costaricensis, A. cantonensis, and $A$. vasorum by polymerase chain reaction- restriction fragment length polymorphism. Mem Inst Oswaldo Cruz. 2003;98(8):1039-43.

131. Denk D, Matiasek K, Just FT, Hermanns W, Baiker K, Herbach N, et al. Disseminated angiostrongylosis with fatal cerebral haemorrhages in two dogs in Germany: a clinical case study. Vet Parasitol. 2009;160(1-2):100-8.

132. Al-Sabi MN, Deplazes P, Webster P, Willesen JL, Davidson RK, Kapel CM. PCR detection of Angiostrongylus vasorum in faecal samples of dogs and foxes. Parasitol Res. 2010;107(1):135-40.

133. Helm J, Gilleard JS, Jackson M, Redman E, Bell R. A case of canine Angiostrongylus vasorum in Scotland confirmed by PCR and sequence analysis. J Small Anim Pract. 2009;50(5):255-9.

134. Patterson-Kane JC, Gibbons LM, Jefferies R, Morgan ER, Wenzlow N, Redrobe SP. Pneumonia from Angiostrongylus vasorum infection in a red panda (Ailurus fulgens fulgens). J Vet Diagn Invest. 2009;21(2):270-3.

135. Jefferies R, Morgan ER, Shaw SE. A SYBR green real-time PCR assay for the detection of the nematode Angiostrongylus vasorum in definitive and intermediate hosts. Vet Parasitol. 2009;166(1-2):112-118.

136. Schnyder M, Jefferies R, Schucan A, Morgan E, Deplazes P. Comparison of coprological, immunological and molecular methods for the detection of dogs infected with Angiostrongylus vasorum before and after anthelmintic treatment. Parasitology. 2015;142(10):1270-7.

137. Houpin E, McCarthy G, Ferrand M, De Waalb T, O'Neillb E, Zintl A. Comparison of three methods for the detection of Angiostrongylus vasorum in the final host. Vet Parasitol. 2016:220:54-8.

138. Traversa D, lorio R, Otranto D. Diagnostic and clinical implications of a nested PCR specific for ribosomal DNA of the feline lungworm Aelurostrongylus abstrusus (Nematoda, Strongylida). J Clin Microbiol. 2008;46(5):1811-7.
139. Annoscia G, Latrofa MS, Campbell BE, Giannelli A, Ramos RA, Dantas-Torres $F$, et al. Simultaneous detection of the feline lungworms Troglostrongylus brevior and Aelurostrongylus abstrusus by a newly developed duplex-PCR. Vet Parasitol. 2014;199(3-4):172-8.

140. Di Cesare A, Veronesi F, Frangipane di Regalbono A, lorio R, Traversa D. Novel molecular ssay for simultaneous identification of neglected lungworms and heartworms affecting cats. J Clin Microbiol. 2015;53(9):3009-13.

141. Dougherty E. The genus Aelurostrongylus Cameron, 1927 (Nematoda: Metastrongylidae), and its relatives; with descriptions of Parafilaroides, gen nov., and Angiostrongylus gubernaculatus, sp. nov. Proc Helm Soc Wash. 1946;13(1):16-25.

142. Ferreira Júnior JA, Blume GR, SKHd S, CMd C, Gardiner C. Anatomopathological aspects of parasitism by nematodes of the superfamily Metastrongyloidea in wild crab-eating fox (Cerdocyon thous) in Midwestern Brazil. Ciencia Rural. 2017;47(2):e20160547.

143. Vieira FM, Muniz-Pereira LC, de Souza-Lima S, Rocha BM, Luque JL. Parasitic nematodes of three species of wild carnivore mammals from Atlantic forest in the state of Minas Gerais, Brazil. Rev Mex Biodivers. 2017;88(4):801-6.

144. Fenerich FL, Santos S, Ribeiro LO. Incidência de Aelurostrongylus abstrusus (Railliet, 1898) (Nematoda: Protostrongylidae) em gatos de rua da cidade de São Paulo, Brasil. O Biológico. 1975;41(2):57-8.

145. Ohlweiler FP, MCdA G, Takahashi FY, Eduardo JM. Current distribution of Achatina fulica, in the State of São Paulo including records of Aelurostrongylus abstrusus (Nematoda) larvae infestation. Rev Inst Med Trop Sao Paulo. 2010;52(4):211-4.

146. Colella V, Cavalera M, Deak G, Tarallo V, Gherman C, Mihalca A, et al. Larval development of Angiostrongylus chabaudi, the causative agent of feline angiostrongylosis, in the snail Cornu aspersum. Parasitology. 2017; 144(14):1922-30.

147. Rosen L, Ash LR, Wallace GD. Life history of the canine lungworm Angiostrongylus vasonim (Baillet). Am J Vet Res. 1970;31:131-43.

148. Bowman DD. Respiratory system parasites of the dog and cat (Part II): trachea and bronchi, and pulmonary vessels. In: Bowman DD, editor. Companion and Exotic Animal Parasitology. Ithaca, New York: International Veterinary Information Service; 2000.

149. McGarry JW, Morgan ER. Identification of first-stage larvae of metastrongyles from dogs. Vet Rec. 2009;165(9):258.

150. Sloss MW, Kemp RL, Zajac AM. Veterinary Clinical Parasitology. 6th ed. Ames: lowa State University Press; 1994.

151. Giannelli A, Capelli G, Hinney B, Joachim A, Losson B, Kirkova Z, et al. Epidemiology, diagnosis and treatment of lungworm and gastrointestinal parasitic infections in cats: an European perspective. Int J Parasitol. 2017; 47(9):517-28.

152. Gerichter CB. Studies on the nematodes parasitic in the lungs of Felidae in Palestine. Parasitology. 1949;39:251-62.

153. Brianti E, Gaglio G, Giannetto S, Annoscia G, Latrofa MS, Dantas-Torres F, et al. Troglostrongylus brevior and Troglostrongylus subcrenatus (Strongylida: (renosomatidae) as agents of broncho-pulmonary infestation in domestic cats. Parasit Vectors. 2012;5:178.

154. Diakou A, Psalla D, Migli D, Di Cesare A, Youlatos D, Marcer F, Traversa D. First evidence of the European wildcat (Felis silvestris silvestris) as definitive host of Angiostrongylus chabaudi. Parasitol Res. 2016;115:1235-44.

155. Gherman CM, Ionică AM, D'Amico G, Otranto D, Mihalca AD. Angiostrongylus chabaudi (Biocca, 1957) in wildcat (Felis silvestris silvestris, S) from Romania. Parasitol Res. 2016;115:2511-7.

156. Kreis HA. Studies on the genus Strongyloides (Nematodes). Am J Hyg. 1932; 16(2):450-91. 